\title{
Examination of Anxiety Levels and Anger Expression Manners of Undergraduate Table Tennis Players
}

\author{
Tamer Karademir*, Ünal Türkçapar \\ School of Physical Education and Sports, Kahramanmaras Sutcu Imam University, Turkey
}

Copyright (C2016 by authors, all rights reserved. Authors agree that this article remains permanently open access under the terms of the Creative Commons Attribution License 4.0 International License.

\begin{abstract}
This research was done for the determination of how their anxiety levels' and anger expressions' get shaped according to some variances. For this reason there were 76 female 125 male totally 201 sportsmen, who participated to the table tennis championship between universities in 2016 and ages differ from 18 to 28, were included the research group. According to research findings it was found that there was not a statistically meaningful difference between permanent anxiety levels and anger expressing types of the sample group according to gender variance $(p>0.05)$, but there were statistically meaningful differences found according to table tennis sports past, being consulted himself for decisions that is going to be made in the family, friendship relations variances $(p<0.05)$. It was also determined that between permanent anxiety levels and permanent anger, anger inward and anger outward point averages there was a positive and linear correlation found, in the anger control point averages there was a negative and linear correlation found. Consequently taking a look to pasts of the table tennis sports which is existed in the normal bounds of the research group's permanent anxiety levels there was a result reached that from anger expression types; anger control point averages' resulted higher than other expression types and when the required attention and concentration were considered for the sports branch that they do it is a good feature.
\end{abstract}

Keywords Table Tennis, Anxiety, Sportsman, Permanent Anger, Anger Control

\section{Introduction}

In every event that a person plays a part there is an important psychological aspect exists. Psychological aspect in the sports is an important factor on people that aim to compete and live healthy. If sport is a social activity then sportsmen need to be dealt as psycho-social organisms in terms of scientific aspect [1].

For increasing the performances of the sportsmen generally condition, technic and tactic trainings are highly done. Scientists and technic men suggested that for the success of the sportsmen technic, tactic and condition trainings are very important. Besides this psychology of the sportsman is also a known reality to increase the success. Generally when successful sportsmen are examined it is seen that they increase their performances by giving importance to psychological trainings besides technic, tactic and condition trainings [2]. Every passing day new speed, power, quickness and etc. training techniques are researched different game tactics and more perfect techniques are tried, searching for better results for the sportsman. These researches showed that for a sportsman to reach the top perfection of the physical capacity is not enough [3]. In the competition sportsmen might be affected from psychological factors that affect their performances in positive or negative way. These factors sometimes about sportsman's personality structure, and sometimes might be the effect of an external stimulant [1].

In sportive activities one of the factors that affect the performance is anxiety that has emotion status and emotive contents.

Anxiety can be at different intensities such as; little nervousness and concern, also can be at panic degree [4]. Anxiety that comes out automatically is the reaction of organism in case of danger [5]. When the person coincides with a situation that he cannot deal with he will probably be caught up to despair emotion. This situation is permanent on the anxious person except for some temporary situations [6].

Anxiety in a way provides the person to adapt to the new conditions, motivate in personality development, has a positive function, but besides this it has a function that blocks adaptation and development [7]. Individuals that have anxiety disorder are uneasy and excited. Even there is not a concrete issue to explain he/she will be caught up to unnecessary anxieties and he/she also cannot realize that this is unnecessary [8].

Anxiety is a thing that an individual consider own self insufficient in a challenging environment. In a situation that individual faces he/she will focus on personal insufficiencies' undesired results. Anxiety is not created by events, illogical 
beliefs of the people lead to anxiety. So the important thing is the meaning assigned to that situation [9].

Anxiety is dealt with two different types; state anxiety and permanent anxiety. State anxiety is the subjective fear that individual feels because of the stressful situation. And physiologically with result stimulant that happens in autonomy nerve system the indicators of emotions and physical changes occurs; sweating, getting red and trembling. According to Spielberger state anxiety is an emotive statement that is characterized with fear, anxiety and nervousness. When stress is intensive there is an increase happen in the state anxiety level, and when stress disappears there is a decrease happens [3].

One of the important factors that affect the adaptation skills, attention and concentrations, self-confidence, condition and balances, decision making and activations of the sportsmen is anger and anger control types.

In daily life emotions that we experience are; happiness, excitement, fear, sadness, anxiety one of the other emotions is anger. Anger is one of the basic emotions that are so ordinary to experience and we experience it so much in our daily life [10]. Anger is possible to be evaluated as an emotional reaction that shows itself at different degrees in the situations towards physical, behavioral and verbal expression types, blocking of expectation and needs [11]. While Spielberger et al [12] define the anger as an emotional statement as simple furiousness or anger that changes from that point to rage statement with a grading system, according to Soykan [13]; anger is quite natural, universal and humanistic reaction that is given to undesired results and unrequited expectations. Anger is one of the five basic emotions, consisted of happiness, sadness, fear and hatred, of human and it a natural affectivity for human [14]. According to West; it is thought that in result of anger's presenting of the social rules and expectations unfairly to everybody [15].

Anger is an emotion that is expressed through verbal and body reaction of human within self-realization [16]. Besides being a natural emotion anger is important how it is explained [17]. When expression types of anger vary, outward of anger; is transmitting to outside verbally or behaviorally and stress that is caused by anger it is the adaptive reaction for dealing with it. According to Averill [18] anger that an individual experiences have occurrence ways such as physiological, verbal, behavioral. When the factors form the anger, it is seen that there was not a reason found. Since Kassinove and Toohey [19] generally do not consider the negative results that angry people do they determined that most of them do not see this as their problem. Yet, it is known that blocking is the most coincided situation in the source of anger. According to Kiper [20], in most of the research conducted about social psychology while aggressive attitudes are developed in an experimental environment; sportive environment has being a natural environment characteristic for finding out these behaviors. It is because blocking which is thought that causes to anger and aggressiveness always exists in the sports.
Being a multiple notion, anger, is defined in different resources with various types. Spielberger et al [21] considered the anger emotion with permanency and state dimensions. According to him state anger blocking of an attitude that intended to an aim or in an injustice perception with which level of objective affectivity experienced such as; nervousness, anger, furiousness, rage. And permanent anger is a notion that reflects how often the state anger experienced generally. By the way; anger control, repression of anger, and expression of the anger dimensions explain how anger is expressed.

Emotions may increase or blocks our performance. Most of the time positive emotions may push you to reach the top. However when your excitement turns into anxiety and aggressiveness turns into anger then you may begin to make faults [2]. Researches that are done in recent days indicate that sportive success does not only depend on biomechanics factors but also it depends on anxiety, stress and motivation [1].

This research was also done for the determination of how college sportsmen's, who play table tennis that requires sudden decision making, concentration and motivation and there has not been much research done on the literature, anxiety statements and anger expression types get shaped according to some variances. Also, the results of the study will be able to direct educators and trainers for the table tennis players that study at the Department of Physical Education and Sport, in developing the coping strategies against the negative psychological circumstances that can be possible at the competitions.

\section{Material and Methods}

\section{Study Group}

There were 76 female 125 male totally 201 sportsmen, who participated to the table tennis championship between universities in 2016 and ages differ from 18 to 28 , included the research group. The sample groups includes table tennis players of the students at universities, including Turkey's general. Information about the content of research was given to sportsmen and they were asked if they want to attend the research or not ones who wanted to participate voluntarily were accepted to the research. Scale forms were provided to be filled out of the competition areas in sportsmen's rest time.

\section{Data Collecting Tools}

Additionally to personal information form for the people who want to participate voluntarily and the first one; the original form was developed by Spielberger et al (1970) and adaptation to Turkish, reliability and validity study was done by Öner and Le Compte [22] the State-Trait Anxiety Inventory was applied. State-Permanent Anxiety Inventory totally consisted of 40 articles and includes two different scales. These two scales that are consisted of twenty each articles used as two different forms. In the study the 
permanent anxiety scale, consisted of 20 articles, was used. In the permanent anxiety articles emotions or behaviors according to frequency degree they are going to be calculated as in the following; Almost never 1 point, sometimes 2 points, most of the time 3 points, almost always 4 points. Inner consistency Cronbach Alpha values for State Anxiety were found .83 and .92, for Permanent Anxiety it was found as .86 and .92. Secondly; In the determination of anger express types the anger and anger style scale, which was developed by Spielberger et al [21], and for our country its reliability/validity was done by Özer [23] was used. Scale consisted of 4 sub scale and 34 articles; Anger inward, Anger outward, anger control and Permanent anger. Evaluation of the scale is done by giving 4 points through; never defines 1 points, it defies somewhat 2 points, it quite defines 3 points, it totally defines 4 points. The lowest point is 8 that can be got from the sub scales of anger inward, anger outward and anger control, the highest point is 32 , the lowest point is 10 that can be got from sub scales of Permanent anger the highest points is 40. According to these scales the Cronbach Alpha values was determined as; for permanent Anger between .82 and .90, for Anger control .85, for anger outward .76 and for anger inward .74.

\section{Analyses of the Data}

Datum that was acquired from research group was analyzed with SPSS package program. In the numeric evaluation of demographical information the frequency and percentage calculations were done. Before the analyzing of the datum their normality distributions were done with Kolmogorov- Simirnov test and for the datum that showed normal distribution the non-parametric tests were used. These are; for mutual comparisons the independent sample t-test and Mann Whitney $U$ test, for multiple comparison tests the one way variance analysis (ANOVA) and Kruscall Wallis $\mathrm{H}$ tests. In the situations that the results of one way variance analyses results found meaningful for the determination of the difference from which group the difference found the posthoc LSD tests were applied. Testing of the relationship between variances the Pearson Correlations test was used. The statistical meaningfulness degree was accepted as $\mathrm{p}<0,05$.

\section{Findings}

Datum that was acquired from research group analyzed and presented in tables in the following.

In the Table 1 it was determined that there was not a statistically meaningful difference found between permanent anxiety and permanent anger and anger expression types according to gender variance.

In the Table 2 according to sports past variance of the research group it was determined that ones with 1-3 years their permanent anxiety statements higher $\left(X^{2}=9,265\right.$; $p<0,05)$, when their anger control $\left(X^{2}=7,440, p<0,05\right)$ levels 7 years and over its higher and this was also statistically meaningful.

In the Table 3 according to parent attitude it was determined that the group that express the parent attitude democratic their anger control point averages higher and this was also statistically meaningful $(\mathrm{F}(2,198)=8,885 ; \mathrm{p}<0,05)$.

In the Table 4 while there was not a difference found on permanent anxiety levels of research group according to asking of the thought in the family variance, on permanent anger $(Z=-3,420 ; p<0,05)$, anger control $(Z=-2,874 ; p<0,05)$ and anger outward $(Z=-2,726 ; p<0,05)$ point averages were on behalf of people who said 'yes' and it also created statistically meaningful difference.

In the Table 5 it was determined that according to friendship relationship variance of the research group the highest level that the group purchased was the one that express their relationship as 'good' and for $(\mathrm{F}(2,198)=7,790$; $\mathrm{p}<0,05)$, anger control $(\mathrm{F}(2,198)=6,416 ; \mathrm{p}<0,05)$, anger outward $(F(2,198)=7,415 ; p<0,05)$ levels of the group that expressed their friendship relationships as 'very good'were more positive.

In the Table 6 it was determined that there was a positive and normal level relationship between permanent anxiety levels and permanent anger $(\mathrm{r}=, 421 ; \mathrm{p}<0.05)$, anger outward $(\mathrm{r}=, 342 ; \mathrm{p}<0.05)$ and anger that is kept inside $(\mathrm{r}=, 471$; $\mathrm{p}<0.05$ ) expression styles, and between permanent anxiety and anger control levels there was a negative and normal level relationship found and it was statistically meaningful $(\mathrm{r}=-, 448 ; \mathrm{p}<0.05)$.

Table 1. Analyses results according to gender variance of the research group

\begin{tabular}{|c|c|c|c|c|c|c|}
\hline & Gender & $\mathrm{N}$ & Mean & Sd. & $\mathrm{t}$ & $\mathrm{p}$ \\
\hline \multirow{2}{*}{ Permanent anxiety } & Female & 76 & 38,59 & 7,16 & \multirow{2}{*}{,- 760} & \multirow{2}{*}{,447 } \\
\hline & Male & 125 & 37,09 & 8,03 & & \\
\hline \multirow{2}{*}{ Permanent anger } & Female & 76 & 19,35 & 4,92 & \multirow{2}{*}{,- 312} & \multirow{2}{*}{, 755} \\
\hline & Male & 125 & 20,21 & 5,12 & & \\
\hline \multirow{2}{*}{ Anger control } & Female & 76 & 23,27 & 4,73 & \multirow{2}{*}{,- 662} & \multirow{2}{*}{,496 } \\
\hline & Male & 125 & 22,81 & 5,19 & & \\
\hline \multirow{2}{*}{ Anger outward } & Female & 76 & 13,25 & 3,98 & \multirow{2}{*}{$-1,653$} & \multirow{2}{*}{097} \\
\hline & Male & 125 & 14,59 & 3,62 & & \\
\hline \multirow{2}{*}{ Anger that is kept inside } & Female & 76 & 13,46 & 2,85 & \multirow{2}{*}{$-1,144$} & \multirow{2}{*}{,253 } \\
\hline & Male & 125 & 14,43 & 3,29 & & \\
\hline
\end{tabular}


Table 2. Analyses results according to sports past variance of the Research group

\begin{tabular}{|c|c|c|c|c|c|c|c|}
\hline & Table Tennis Sport Past & $\mathrm{n}$ & Mean & $\mathrm{SD}$ & $\mathrm{X}^{2}$ & $\mathrm{p}$ & $\begin{array}{c}\text { Diff. } \\
\text { U test }\end{array}$ \\
\hline \multirow{3}{*}{$\begin{array}{l}\text { Permanent } \\
\text { Anxiety }\end{array}$} & a) $1-3$ years & 108 & 41,62 & 7,90 & \multirow{3}{*}{9,265} & \multirow{3}{*}{, $006^{*}$} & \multirow{3}{*}{$\begin{array}{l}a>b \\
c>b\end{array}$} \\
\hline & b) 4-6 years & 58 & 35,42 & 6,40 & & & \\
\hline & c) 7 years and over & 35 & 39,25 & 7,58 & & & \\
\hline \multirow{3}{*}{ Permanent anger } & a) 1-3 years & 108 & 20,24 & 6,40 & \multirow{3}{*}{, 017} & \multirow{3}{*}{,995 } & \\
\hline & b) 4-6 years & 58 & 20,01 & 5,06 & & & \\
\hline & c) 7 years and over & 35 & 19,87 & 4,12 & & & \\
\hline \multirow{3}{*}{ Anger control } & a) 1-3 years & 108 & 22,23 & 6,88 & \multirow{3}{*}{7,440} & \multirow{3}{*}{, $020 *$} & \multirow{3}{*}{$\mathrm{c}>\mathrm{a}$} \\
\hline & b) 4-6 years & 58 & 23,56 & 4,50 & & & \\
\hline & c) 7 years and over & 35 & 23,89 & 4,78 & & & \\
\hline \multirow{3}{*}{ Anger outward } & a) 1-3 years & 108 & 13,85 & 4,58 & \multirow{3}{*}{4,973} & \multirow{3}{*}{, 060} & \\
\hline & b) 4-6 years & 58 & 13,76 & 3,67 & & & \\
\hline & c) 7 years and over & 35 & 14,25 & 2,88 & & & \\
\hline \multirow{3}{*}{$\begin{array}{l}\text { Anger that is } \\
\text { kept inside }\end{array}$} & a) 1-3 years & 108 & 14,58 & 2,85 & \multirow{3}{*}{1,052} & \multirow{3}{*}{, $048^{*}$} & \\
\hline & b) 4-6 years & 58 & 13,33 & 2,83 & & & \\
\hline & c) 7 years and over & 35 & 14,31 & 3,69 & & & \\
\hline
\end{tabular}

$* \mathrm{p}<0,05$

Table 3. Analysis results according to father attitude variance of the research group

\begin{tabular}{|c|c|c|c|c|c|c|c|}
\hline & Parent Attitude & $\mathrm{n}$ & Mean & SD & $\mathrm{F}$ & $\mathrm{p}$ & $\begin{array}{l}\text { Diff. } \\
\text { LSD }\end{array}$ \\
\hline \multirow{3}{*}{ Permanent anxiety } & 1. Democratic & 98 & 37,37 & 7,46 & \multirow{3}{*}{, 407} & \multirow{3}{*}{, 816} & \\
\hline & 2.Authoritative & 41 & 39,07 & 6,30 & & & \\
\hline & 3. Protecting & 62 & 38,22 & 8,07 & & & \\
\hline \multirow{3}{*}{ Permanent anger } & 1. Democratic & 98 & 18,97 & 3,41 & \multirow{3}{*}{1,331} & \multirow{3}{*}{, 514} & \\
\hline & 2.Authoritative & 41 & 20,53 & 4,59 & & & \\
\hline & 3. Protecting & 62 & 20,94 & 6,45 & & & \\
\hline \multirow{3}{*}{ Anger control } & 1. Democratic & 98 & 25,29 & 4,30 & \multirow{3}{*}{8,885} & \multirow{3}{*}{, $007 *$} & \multirow{3}{*}{$1>2,3$} \\
\hline & 2.Authoritative & 41 & 21,61 & 4,59 & & & \\
\hline & 3. Protecting & 62 & 21,94 & 5,64 & & & \\
\hline \multirow{3}{*}{ Anger outward } & 1. Democratic & 98 & 14,37 & 2,94 & \multirow{3}{*}{, 370} & \multirow{3}{*}{, 831} & \\
\hline & 2.Authoritative & 41 & 14,07 & 4,07 & & & \\
\hline & 3. Protecting & 62 & 14,31 & 4,38 & & & \\
\hline \multirow{3}{*}{$\begin{array}{l}\text { Anger that is kept } \\
\text { inside }\end{array}$} & 1. Democratic & 98 & 13,75 & 3,16 & \multirow{3}{*}{1,973} & \multirow{3}{*}{, 373} & \\
\hline & 2.Authoritative & 41 & 14,84 & 2,76 & & & \\
\hline & 3. Protecting & 62 & 14,45 & 3,42 & & & \\
\hline
\end{tabular}

$* \mathrm{p}<0,05$

Table 4. Analysis results according to asking of the thought of research group in the family

\begin{tabular}{|c|c|c|c|c|c|c|}
\hline & Asking of the thought in family & $\mathrm{N}$ & Mean & SD & U test & $\mathrm{p}$ \\
\hline \multirow{2}{*}{ Permanent anxiety } & yes & 167 & 37,68 & 7,51 & \multirow{2}{*}{$-1,038$} & \multirow{2}{*}{,299 } \\
\hline & no & 34 & 40,30 & 7,36 & & \\
\hline \multirow{2}{*}{ Permanent anger } & yes & 167 & 19,14 & 4,24 & \multirow{2}{*}{$-3,420$} & \multirow{2}{*}{, $001^{*}$} \\
\hline & no & 34 & 26,60 & 6,18 & & \\
\hline \multirow{2}{*}{ Anger control } & yes & 167 & 23,94 & 4,87 & \multirow{2}{*}{$-2,874$} & \multirow{2}{*}{, $004^{*}$} \\
\hline & no & 34 & 18,90 & 5,42 & & \\
\hline \multirow{2}{*}{ Anger outward } & yes & 167 & 13,82 & 3,31 & \multirow{2}{*}{$-2,726$} & \multirow{2}{*}{, $006^{*}$} \\
\hline & no & 34 & 17,90 & 4,77 & & \\
\hline \multirow{2}{*}{ Anger that is kept inside } & yes & 167 & 14,06 & 3,21 & \multirow{2}{*}{$-1,529$} & \multirow{2}{*}{, 126 } \\
\hline & no & 34 & 15,30 & 3,16 & & \\
\hline
\end{tabular}


Table 5. Analysis results according to friendship relationship of the research group

\begin{tabular}{|c|c|c|c|c|c|c|c|}
\hline & $\begin{array}{l}\text { Friendship } \\
\text { Relationship }\end{array}$ & $\mathrm{n}$ & Mean & SD & $\mathrm{F}$ & $\mathrm{p}$ & $\begin{array}{l}\text { Diff. } \\
\text { LSD }\end{array}$ \\
\hline \multirow{3}{*}{$\begin{array}{l}\text { Permanent } \\
\text { anxiety }\end{array}$} & 1. normal & 51 & 37,83 & 6,96 & \multirow{3}{*}{7,790} & \multirow{3}{*}{, $020^{*}$} & \multirow{3}{*}{$2>1,3$} \\
\hline & 2. good & 88 & 40,41 & 6,67 & & & \\
\hline & 3. very good & 62 & 35,97 & 7,78 & & & \\
\hline \multirow{3}{*}{ Permanent anger } & 1. normal & 51 & 23,16 & 5,11 & \multirow{3}{*}{3,076} & \multirow{3}{*}{, 215} & \\
\hline & 2. good & 88 & 19,63 & 5,15 & & & \\
\hline & 3. very good & 62 & 19,90 & 4,97 & & & \\
\hline \multirow{3}{*}{ Anger control } & 1. normal & 51 & 22,00 & 4,00 & \multirow{3}{*}{6,416} & \multirow{3}{*}{, $040^{*}$} & \multirow{3}{*}{$3>1,2$} \\
\hline & 2. good & 88 & 21,75 & 5,24 & & & \\
\hline & 3. very good & 62 & 24,88 & 4,89 & & & \\
\hline \multirow{3}{*}{ Anger outward } & 1. normal & 51 & 16,00 & 2,00 & \multirow{3}{*}{7,415} & \multirow{3}{*}{, $025^{*}$} & \multirow{3}{*}{$1>2,3$} \\
\hline & 2. good & 88 & 13,30 & 3,77 & & & \\
\hline & 3. very good & 62 & 14,90 & 3,70 & & & \\
\hline \multirow{3}{*}{$\begin{array}{l}\text { Anger that is kept } \\
\text { inside }\end{array}$} & 1. normal & 51 & 16,00 & 3,03 & \multirow{3}{*}{2,499} & \multirow{3}{*}{, 287} & \\
\hline & 2. good & 88 & 14,30 & 2,97 & & & \\
\hline & 3. very good & 62 & 13,88 & 3,40 & & & \\
\hline
\end{tabular}

$* \mathrm{p}<0,05$

Table 6. Correlation analysis between permanent anger and anger expression styles of the research group

\begin{tabular}{|c|c|c|c|c|c|c|}
\hline \multicolumn{2}{|c|}{ Scale } & 1 & 2 & 3 & 4 & 5 \\
\hline \multirow{3}{*}{ Permanent Anxiety } & $\mathrm{R}$ & 1,000 & & & & \\
\hline & $\mathrm{P}$ & . & & & & \\
\hline & $\mathrm{N}$ & 201 & & & & \\
\hline \multirow{3}{*}{ Permanent anger } & $\mathrm{R}$ &, $421^{*}$ & 1,000 & & & \\
\hline & $\mathrm{P}$ &, 003 & . & & & \\
\hline & $\mathrm{N}$ & 201 & 201 & & & \\
\hline \multirow{3}{*}{ Anger control } & $\mathrm{R}$ &,$- 448^{*}$ &,$- 367^{*}$ & 1,000 & & \\
\hline & $\mathrm{p}$ &, 000 &, 001 & . & & \\
\hline & $\mathrm{N}$ & 201 & 201 & 201 & & \\
\hline \multirow{3}{*}{ Anger outward } & $\mathrm{r}$ &, $342^{*}$ & $683^{*}$ &,$- 372^{*}$ & 1,000 & \\
\hline & $\mathrm{p}$ & ,003 & , 000 &, 000 & . & \\
\hline & $\mathrm{N}$ & 201 & 201 & 201 & 201 & \\
\hline \multirow{3}{*}{ Anger that is kept inside } & $\mathrm{r}$ &, $471^{*}$ &, $474^{*}$ &,$- 249^{*}$ &, $520^{*}$ & 1,000 \\
\hline & $\mathrm{p}$ & ,000 &, 000 &, 021 &, 000 & . \\
\hline & $\mathrm{N}$ & 201 & 201 & 201 & 201 & 201 \\
\hline
\end{tabular}

$* \mathrm{p}<0,05$

\section{Discussion and Conclusion}

Acquired findings from research group were discussed in the light of literature information. According to this; there was not a statistically meaningful difference found between permanent anxiety, permanent anger and anger expression styles according to gender variance (Table 1.). While some determined that there was meaningful difference on the anxiety levels according to gender [24] [25] 26], there are also studies that determine there is not a difference found [27] [28]. In some conducted researches while it was determined that there may be meaningful difference on the anger expression types of the male and female sportsmen, male sportsmen outward their anger and females do this through more secret ways [29], but on a study that was done on physical education and sports academy students it is determined that there was not a difference found between permanent anger and anger expression types [30]. When the related body of literature examined it was being determined that girls do not outward their anger and they frequently experience anger and they also related this situation with girls' being ladylike roles which is burdened by the society and that society's culture. Boys can feel the anger and for their expression of anger mostly consisted of screaming, damaging environment, fighting behaviors and mostly this is out warded and anger types are practised [31].

According to table tennis sport past variance of the research group permanent anxiety statements' of them are higher with few sport past and their anger control levels' are higher on the people with few sports past when compared to other groups and this situation was determined statistically meaningful (Table 2.). It is determined that cognitive 
behaviorist approaches is a learnt behavior of the anger expressing type [32]. In this meaning, people with higher sport past discipline of sports itself it might be occurred in the way of anger control type more than anger expressing type. Inward of the anger is an alternative adaptation mechanism that person hide or keeping the anger inside again existing anger factors [33]. Besides this, anger emotion has a function in the nature of human and anger emotion is not an emotion that has not got function. Situation that prevents the anger emotion to carry on its function is out warding of it and individuals turning around own self [34].

It was determined that the group that expresses the parent attitude as democratic their anger control point averages was higher and this situation determined statistically meaningful (Table 3.). Anger control are the experiences that expresses how a person control his anger in relationship with other people or how he/she controls or how he' she tends to be in calm mood, and it is the control experiences on individual reactions for anger expression [33]. Carrasco et al [35] conducted a study for the aim of measuring today and future lives of the children for anger levels effect and there were important relationships found out. Firstly, there was a relationship found between parent hostility (with father and mother or both of the couple to each other) and aggressiveness of the child that confirms the previous studies. In other words, processing of the child's anger and aggressiveness behavior is derived from his/her parent's hostile emotions and it leads child internalize the aggressiveness in the future. Thus in the long run it leads to be inured of the aggressiveness. Consequently it can be inferred that child's today and future aggressiveness is based on his/her parent's responsibility and their attitudes. It is because the child realizes that socializing process by making relationship with his parents' behaviors. Just from the childhood period it can be possible to say that in results of positive cognitive attitude and behaviors that are acquired in family environment individuals may be more controllable to change the negative issues to the positive. And results of conducted studies are in favor of the situation that the groups who express parent attitudes democratic are more controllable when compared to ones who express it as authoritative and protective.

While there was not a difference found permanent anxiety levels according to thought asking variance of the research group, there was a statistical and meaningful difference found for the goodness of the ones that say yes in the averages of permanent anger, anger control and outward anger (Table 4.). In the literature on a research that was done by Albayrak and Kutlu [36], students that have no right to talk about domestic issues their anger pressure was found higher than other students. Similarly in the same research, it is seen that individuals that are with dominant family attitude and define themselves as pressure creative they reflect to anger to outside much more. And this means that individuals are redirected to their inner world for the destructiveness of the anger when they are not let enough to talk about family issues and not enough conditions provided to them [37].
When the literature is examined common result of the researches show that pressure and authoritative attitude; prevent individuals' proving themselves and realize themselves, damage their self-confidence, lead to worried depending, increase the social anxiety level and especially boys' aggressiveness levels [38, 39]. In a conducted research by Clarey et al [40] in Mexico on 204 high school students there was a relationship found between anger control, anger expression style and exposure to parent conflict, being exposed to violence. Research results show that children that are exposed to domestic violence may learn the violence as an expression style and these people have a big risk for applying the violence to people around them.

When friendship relationship are examined it was found that permanent anxiety levels of the research group was high that express the friendship relations good according to this variance (Table 5.). This situation can be occurred from personality characteristics of the sample group and it can also be derived from ones that have stress in the group. It is seen that ones who have more positive relationships about anger control and outward anger their friendship relationship is at a nice level (Table 5.). A warm relationship may help to children be responsible and they can control themselves, help to develop their personality and the hostile relationship is in tendency of supporting the anger and aggressiveness [41]. According to this model the mechanism that people learn for being aggressive is learning with taking as a model. Researchers, specify that people especially in tending of imitation the behaviors of humans that they are keen on and envy [42]. And this can develop their future attitude and behaviors.

Another finding that was acquired from research; is the thing that there is a normal level and positive relationship on the permanent anxiety levels and permanent anger, outward anger and anger that is kept inside of the research group, and there was a normal and negative direction relationship between permanent anxiety and anger control levels and this is statistically meaningful (Table 6.). Anxiety on the sportive performance anxiety importantly affects the adaptation skills of the sportsmen, their attention, condition and balances, making decision and evaluations, self-confidence and worthiness, motivation and activations. These effects show themselves on the sportsmen in terms of their need of power, speed, durability, flexibility, technic and tactic characteristics for their performances [1]. When sportsmen are worried their bodies go out of control and it makes many stimulants. Some of the stimulants are; tension of muscles, cannot be concentrated, nauseation, increasing of tension and breathe speed, turning back to old habits and forgetting the details. At the same time they may coincide with losing of easiness in motions and neatness, disorders in control and concentrations [3]. These situations may create a disadvantage for sportsmen's performances. Therefore, depend on environmental reasons that create anxiety situations and perceived as threat reflect on personality characteristics it will be nice for the determination of external factors. 
Consequently, it was found that there was not a statistically meaningful difference between permanent anxiety levels and anger expression types of the research group according to gender variance $(p>0,05)$, there were meaningful differences found on table tennis sport past, being consulted their thoughts in the family, and friendship relationships variances $(p<0,05)$. No matter which sports branch that sportsmen do they need to a specific anxiety levels for the performance. When the required attention and concentration for the sport branch is considered it was reached that this a good characteristic for the sportsmen within the permanent anxiety levels of the research group at normal boundaries from anger expression styles their anger control point averages are higher when compared to other expression types besides this, it can be said that each sport branch has cognitive acquirements and having discipline characteristic have positive effect on sportsmen that are dealing with table tennis sport.

\section{REFERENCES}

[1] Yücel EO. The state trait anxiety and its effects on success in championship for taekwondo players, Master's thesis, Gazi University Health Sciences Institute Physical Education and Sports Department, Ankara, 2003.

[2] Civan A. Comparison of State and Permanent Anxieties in the Individual and Team Sports before and After Competition, Master Degree Thesis, Selçuk University Health Sciences Institute Physical Education and Sports Department, Konya, 2001.

[3] Özgül F. State and trait anxiety of the students in Cumhuriyet University School of Physical Training and Sports, Unpublished master's thesis, Cumhuriyet University Health Sciences Institute Physical Education and Sports Department, Sivas, 2003.

[4] Çakır S. The effect of 'overcoming social anxiety program', which is based on the cognitive behaviorist approach, on high school students' level of social anxiety Unpublished master's thesis, Uludağ University Social Sciences Institute, Bursa, 2010

[5] Köknel Ö. From Anxiety to Fear. Istanbul: Remzi Book Store, 2014.

[6] Geçtan E. Being Human. (12th Press) Istanbul: Metis Publishing, 2014.

[7] Göktürk YG. A study of social anxiety of adolescents according to self-esteem and some personal and demographic characteristics, Unpublished master's thesis, Abant İzzet Baysal University Education Sciences Institute Guiding and Psychological Counselling Department. Bolu, 2011.

[8] Burkovik F. What is the big deal for worrying! (Third Press). Istanbul: Timaş Publishing, 2013.

[9] Wilde J. Treatting anger, anxiety, and depression in children and adolescents. United States of America: Taylor \& Francis Ltd, 1995.
[10] Öztürk E. Control management and causes of anger in trainers who work in primary school: Sample of Elazığ city, Unpublished master's thesis, Firat University Education Sciences Institute, Elazığ, 2012.

[11] Karademir T, Çoban B, and Açak M. The Evaluation of Trait Anger and Expressions of Anger in Elite Taekwondo Athletes, 11. International Sports Sciences Congress Poster Presentation, 10-12 Kasim 2010, Antalya, 2010.

[12] Spielberger CD, Crane RS. and Kearns WD. Anger and anxiety in essential hypertensions, Stress and Emotion: Anxiety, Anger and Curiosity, 265-279, 1991.

[13] Soykan Ç. Anger and Anger Management, Kriz Journal, 11(2): 19-27, 2003.

[14] Alberti R and Emmons M. Use your Initiativeness Right, First Press, (Translator: Katlan, S.), Ankara, HYB Publishing, p:107-123, 1998.

[15] Stephen DS. AngerExperiens in Violent and No-Violent male Offenders, Florida, Phd. University of Miami, 2004.

[16] Eckhardt C, Norlander B and Deffenbacher J. The assessment of anger and hostility: A critical review. Aggression and Violent Behavior, 9, 17-43, 2004.

[17] Baltaş Z and Baltaş A. Stress and deaking ways. (30th Press). Istanbul: Remzi Book Store, 2013.

[18] Averill JR. Studies on anger and aggression: Implications for theories of emotion. Am Psychol, 38: 1145-1160, 1983.

[19] Kassinove H and Toohey MJ. Dys functional adult anger: Basic issues and treatment strategies. In L. Grossman and S. Walfish. Translating Research into Practice: A Desk Reference for Practicing Mental Health Professionals. Springer, 2014.

[20] Kiper İ. Aggressiveness Types' Relationship with Economic, Social and Academic Variances, Unpublished Master Degree Thesis, Ankara University Social Sciences Institute, Ankara, 1984.

[21] Spielberger CD, Jacobs G, Russell S and Crane RS. Assessment of Anger: The State-Trait Anger Scale, Advances in Personality Assessment, 161-186, 1983.

[22] Öner N and Le Compte A. Discontinuous State/ State-Trait Inventory Booklet, Boğaziçi University Publishing, p.1,3, İstanbul, 1983

[23] Özer, K. Prestudy of Permanent Anger (SL-Anger) and Anger Expression Type (Öfke- Tarz) Scales, Turkish Psychology Journal, 9(31):26-3, 1994.

[24] Karaman S. The state and trait anxiety levels of university students studying health-related education program, Master's thesis, Erciyes University, Health Sciences Institute. Kayseri, 2009.

[25] Başaran SS. Analysis of the constant concern levels, self-efficacy perceptions of the pre-school music teachers and their attitudes towards music teaching as a profession with respect to various variables, Master's thesis, Zonguldak Karaelmas University, Social Sciences Institute. Zonguldak, 2010.

[26] Raes F. Rumination and worry as mediators of the relationship between self-compassion depression and anxiety. Personality and Individual Differences 48, 757-761, 2010 . 
[27] Develi E. The investigation of the permanent worry state of physical education teachers who work at elementary schools in Konya, Master's thesis, Selçuk University, Health Sciences Institute. Konya, 2006.

[28] Tekkoyun M. The effect of the number of pupils in a class on stress and anxiety conditions of primary school first level class teachers: Küçükçekmece example, Master's thesis, Beykent University, Social Sciences Institute. İstanbul, 2008.

[29] Sharkin BS. Anger and gender: theory, research and implications. J Couns Dev, 71: 386-389, 1993.

[30] Akpınar Ö. Examination of physical education and sports in college students studying self - sufficiency and trait anger and anger expression, Unpublished master's thesis, Karamanoğlu Mehmetbey University Social Sciences Institute Physical Education and Sports Department, Karaman, 2015.

[31] Soysal Ş, Can H and Kılıç KM. Analysis of the Type A Behavior Pattern and Anger Expression on University Students and Its comparison In terms of Genders. Clinic Psychiatry Journal, 12, 61- 67, 2009.

[32] Özmen A. Anger: theoretical Approaches and Factors that Cause to Occurrence of Anger on Individuals. Ankara University Education Sciences Faculty Journal, 39, issue:1, pp.39-56, 2004.

[33] Starner TM and Peters RM. Anger expression and blood pressure in adolescents. The Journal of School Nursing,20 (6): 335-342, 2004.

[34] Westermayer J. Alcoholism and Co-morbid Psychiatric Disorders Among American Indians, A.B.D.: Denver, 2001.
[35] Carrasco MA, Holgado FP, Rodríguez MA and Del Barrio MV. Concurrent and Across-Time Relations between Mother / Father Hostility and Children's aggression: A longitudinal study. Journal of Family Violence, 24(4): 213-220, 2009.

[36] Albayrak B and Kutlu Y. Factors that are related with Anger Expression Type on Adolescents. Maltepe University Nursery Science and Arts Journal, 2, 3, 2009.

[37] Uslu EB. The examination of 14-17 ages adolescents anger expression styles according to rearing attitudes of family, Master thesis, Beykent University, Social Sciences Institute Psychology Department, Istanbul, 2015.

[38] Çeçen R. Examination of Loneliness and Social Support Levels of the Students According to Genders and Parent Attitude Perceptions. Turkish Education Sciences Journal, 6(3): 415-431, 2008.

[39] Keskin G and Çam O. Examination of the Relationship between Spiritual Statements of the Adolescents and Parent Attitudes and Depending Styles. Anatolia Psychiatry Journal, 9 (83), 139-147, 2008.

[40] Clarey A, Hokoda A and Ulloa EC. Anger Control and Justification of Violence as a Mediator in the Relationship between Witnessing Interparental Violence and Perpetration of Dating Violence in Mexican Adolescents. Journal of Family Violence, 25, 619-625, 2010.

[41] Gander JM and Gardiner HW. Child and Adolescent Development (Ed. B. Onur), Ankara: İmge Book Store, 275-276, 1993.

[42] Baron R and Byrne A. Aggression, Social Psychology, SA, 11: 438-476, 2000 